\title{
Effect of Convention Bureau Experience on Destination Attributes
}

\author{
Hidekazu Iwamoto*, Tokuro Matsuo ${ }^{\dagger}$, Toshikazu Fukushima",
}

\begin{abstract}
Convention host cities are competing to attract profitable exhibition because of economic ripple impact. According to Japan Tourism Agency, economic ripple impact which convention industry in 2015 produces is 590.5 billion. Among the stakeholders, convention bureaus play an important role to attract convention business in Japan. This study focuses on convention bureaus' perception about destination attributes and discusses how the convention bureaus' experience affect the evaluation. The questionnaire was conducted at the $26^{\text {th }}$ International Meetings Expo (IME 2016). In method, each respondents' evaluation was analyzed in descriptive statistics and then respondents are classified into 2 groups; non-experienced group who have not attracted international convention and experienced group who have attracted international convention one or more. In descriptive statistics, the findings indicate that it is important to promote collabora-tion among stakeholders. In logistic regression, the experienced convention bureaus tend to have higher awareness of having foreign-affiliated hotels in host cities than the non-experienced.
\end{abstract}

Keywords: MICE; Convention Bureau; Convention Industry, Questionnaire Survey

\section{Introduction}

In 2016, the total number of foreign visitors in Japan reached over 24.04 million, which is the highest growth rate recorded since 1964. In the tourism industry convention is rapidly emerging as one of the most important segments. Convention industry is classified as four categories: the acronym, 'MICE' (Meetings, Incentives, Convention/Congress, and Exhibition/Event).

\footnotetext{
* Josai International University, Chiba, Japan

$\dagger$ Advanced Institute of Industrial Technology Tokyo Metropolitan University, Tokyo, Japan

* JBE, Inc., Tokyo, Japan
} 
Rogers [1] defines convention as bellows;

"Gathering of delegates, representatives, and members of a members or industry organization convened for a common purpose. Common features include educational sessions, committee meetings, social functions, and meetings to conduct the governance business of the organization. Conventions are typically recurring events with specific, established timing (p.22)."

Japanese government announces the tourism nation promotion basic plan based on the tourism nation promotion basic law in 2007. Promotion of meeting industry is included in one of the aims of the tourism nation promotion basic plan. According to Japan Tourism Agency [2], economic ripple impact which convention industry in 2015 produces is 590.5 billion, which totals 265.5 billion as direct economic impact and 325 billion as indirect economic impact. The reason why the convention industry produces huge economic impact is that delegates tend to stay longer than pleasure travelers, so the convention industry benefits the local economy and act as economic hubs to surrounding areas [3][4]. For example, host cities can benefit from meals, accommodation, sightseeing, shopping, and so on as additional factors. Therefore, convention host cities are competing to attract profitable exhibitions. Asian countries are taking aggressive measures in this field of global marketing. As Japan's position of dominant host city for convention industry in Asia has tended to come down since 2000s, so the competitiveness of convention industry is declining in comparison with other countries [5].

Various stakeholders are concerned in convention industry. Among the stakeholders, convention bureaus play an important role to attract convention business in Japan. Convention bureaus have been regarded as important organizations in the tourism industry [6]. Moreover, convention and visitor bureaus provide official information to the future visitors [7]. They make an effort to collect useful information for presentations to the planners. Thus, convention bureaus play an important role in various aspects. The experiences of convention bureaus hold one of the key components of success in the convention industry. However, researches on convention industry and especially convention bureaus are still limited and just gets started in Japan. Therefore, this study is to clarify what kinds of factors are important to attract international convention for convention bureaus. Moreover, this study discusses the differences between non-experienced and experienced convention bureaus. The findings of this study not only make clear of how the convention bureaus' experience affect the evaluation, but also aims at sharing results with researchers which have similar interests in convention industry.

\section{Literature Review}

\subsection{Previous studies related to destination attributes}

Many criteria for destination attributes have been clarified by previous studies. Oppermann [8] carried out a questionnaire survey and concluded 15 decision criteria. The results showed that respondents regard meeting room facilities and hotel service quality as top priority. Crouch and Bitchie [9] analyzed 64 academic journals and categorized 9 factors such as accessibility, local support, extra-conference opportunities, accommodation facilities, meeting facilities, information, site environment, other criteria as most important.

In addition, $\mathrm{Qu}, \mathrm{Li}$, and $\mathrm{Chu}[10]$ examined satisfaction levels of Hong Kong as an international conference destination. As results, 20 site selection criteria were evaluated by all respondents. Among these, modern-audio-visual equipment, modern hotel facilities, and 
accessibility are ranked in the top three. Chen [11] classified five factors in the process of convention site selections; meeting and accommodation facilities, costs, site environment, local support, and extra conference opportunities and found out that meeting and accommodation facilities and site environment are dominating factors. These researchers point out that accommodation facilities and meetings facilities are crucially important factors to attract international convention. Regarding facilities, Whitfield [12] stated that conference and event organizers tended to choose unique venue in order to make an impression.

On the other hand, Kim, Guo, and Agrusa [13] indicated the importance of tourism facilities to attract international convention and regarded inexpensive travel cost, level of economic development, beautiful scenery, safety, good place for shopping, different cultural and historical resources, good weather, good leisure and recreation facilities, easiness to arrange travel plans, and well-equipped tourism facilities as important factors.

Using important factors cited from the previous studies, this study conducts a questionnaire survey to convention bureaus to analyze what kinds of factors are important to attract international convention in destination attributes.

\subsection{Previous studies related to convention bureaus}

Convention bureaus can be a critical factor in an environment where competition among destinations for convention intensifies [14]. There have been a small number of studies that focus on convention bureaus in Japan.

In the researches related to convention bureaus in Japan, Iwamoto, Matsuo, Fukushima, and Komoda [15] conducted a questionnaire survey with convention bureaus in order to clarify the current advantages and weak points of the city in which the convention is held. The results showed that major advantages are good public security, rich in historical properties, and unique culture. On the other hand, weak points given by convention bureaus are special food supply, English proficiency of officers, English Web pages, and multilingual display in local areas.

In addition, Iwamoto, Matsuo, Fukushima, and Komoda [16] focused on the evaluation of convention bureaus, taking into account its regional characteristics and convention facilities. The results of the questionnaire survey showed that it is necessary to take sufficient measures against area information such as variety of hotel information on the web, local service such as a variety of multilingual sign, and convention facilities such as available of day care center for kids. Regarding destination characteristics and public relation activities, there are following previous studies that focus on the factors as important decision criteria.

Besides, Iwamoto, Matsuo, Fukushima, Komoda [17] discussed the evaluation between non-experienced and experienced convention bureaus with regards to the regional characteristics that each region has. The results showed that the experienced tended to have high awareness of providing local information, while the non-experienced tended to have high awareness of providing the best service as hospitality in the local area.

Previous studies show that the experiences of convention bureaus have one of the key components of success in convention industry. However, researches which focus on convention bureaus are still limited. Therefore, this study covers which factors are important for 
convention bureaus to attract international convention and discusses how the convention bureaus' experience affect the evaluation through a questionnaire survey.

\section{Method}

\subsection{Data Collection}

The questionnaire survey was conducted at the 26th international Meetings Expo (IME 2016) held on December 6-7, 2016, at Pacifico Yokohama, Japan and by online from mid-March to mid-April, 2017. IME is known as the only domestic tradeshow dedicated to MICE. There are 1,287 visitors in IME 2016. The target population in this study consist of convention bureaus in Japan. Researchers collected 101 questionnaires, out of which 91 questionnaires were used for the analysis because these questionnaires included partially incomplete answers. The purpose of this questionnaire is to examine importance of destination attribute by convention bureaus.

The questionnaire is composed of two parts. In the first part, the questionnaire includes demographic information regarding respondents' background such as gender, age, educational background, specialty, workplace, and job position. In the second part, respondents are asked 20 questions to rate important items to attract international convention. This part is measured on a 5-point Likert scale of the importance, ranging from 1 (least important) to 5 (highly important). The questions of this part are consisted of 5 domains: accommodation $\&$ dining, facility, cooperation system, tourism, and access to information.

\subsection{Data Analysis}

Data analysis was conducted in three steps. First, each respondent's demographic factors were analyzed in descriptive statistics. Next, each respondent's evaluation was analyzed in descriptive statistics. In this part, respondents are classified into 2 groups; non-experienced group who have not attracted international convention and experienced group who have attracted international convention one or more time. Finally, a binary logistic regression was conducted to clarify whether there would be any variables showing significant differences in non-experienced and experienced convention bureaus. Logistic binary regression is used for a two-value response. This model is utilized in the case of a situation where two possible results are expected. As stated in the previous studies, convention bureaus play a pivotal role in convention industry. By comparison with experienced convention bureaus, non-experienced convention bureaus can share the information and grasp the differences between them. To see the differences between non-experienced and experienced group and tendencies to choose the important items by each group, logistic regression is one of the effective ways. Therefore, this study adopts logistic regression. In this study, dependent variable is non-experienced and experienced group and independent variables are 20 items shown in table 2.

\section{Result}

\subsection{Demographic information of respondents}

The demographic profiles of the respondents are shown in Table 1. The gender composition of the respondents was female (29\%) and male (71\%). Regarding age group, majority of the respondents was between the ages of 40 s and 50 s. 40 s $(26 \%)$ and 50 s (33\%) 
account for more than half of the respondents. In educational background, more than $70 \%$ of the respondents were undergraduate. In the respondents' specialty, law was the highest, economics in the second place, and linguistics in the third place. In the items of the respondents' workplace, 'Hokaido \& Tohoku', 'Kanto \& Koshinetsu', 'Chubu', 'Kinki', 'Chugoku \& Shikoku', and 'Kyushu \& Okinawa' were 14\%, 17\%, 22\%, 7\%, 21\% and 20\% respectively.

Concerning job position, more than half of the respondents were manager. Staff was the second highest score. In the duration of service in convention industry, 'less than one year', 'one to three years', 'four to six years', 'seven to nine years', and 'more than ten years' were $7 \%, 41 \%, 17 \%, 8 \%$, and $29 \%$ respectively. Regarding number of international convention, you have attracted before, $40 \%$ of the respondents answered that they have not attracted the international convention. 'one to two times', 'three to five times', 'six to ten times', 'eleven to twenty times' and 'more than twenty-one times' respectively.

Table 1: Demographic information of respondents

$(\mathrm{N}=91)$

\begin{tabular}{|c|c|c|}
\hline Variables & Frequency $(\mathrm{n})$ & Percent (\%) \\
\hline \multicolumn{3}{|l|}{ Gender } \\
\hline Female & 26 & 29 \\
\hline Male & 65 & 71 \\
\hline \multicolumn{3}{|l|}{ Age } \\
\hline $20 \mathrm{~s}$ & 5 & 6 \\
\hline $30 \mathrm{~s}$ & 19 & 21 \\
\hline $40 \mathrm{~s}$ & 24 & 26 \\
\hline $50 \mathrm{~s}$ & 30 & 33 \\
\hline 60s and over & 13 & 14 \\
\hline \multicolumn{3}{|l|}{ Educational background } \\
\hline High school & 10 & 11 \\
\hline Vocational school & 6 & 7 \\
\hline Junior college and undergraduate & 69 & 76 \\
\hline Postgraduate & 6 & 7 \\
\hline \multicolumn{3}{|l|}{ Specialty } \\
\hline Literature & 4 & 4 \\
\hline Science & 1 & 1 \\
\hline Agriculture & 1 & 1 \\
\hline Sociology & 8 & 9 \\
\hline Pedagogy & 1 & 1 \\
\hline Economics & 16 & 18 \\
\hline Business & 2 & 2 \\
\hline Linguistics & 10 & 11 \\
\hline Engineering & 4 & 4 \\
\hline Tourism & 5 & 6 \\
\hline Law & 25 & 28 \\
\hline Politics & 3 & 3 \\
\hline Others & 11 & 12 \\
\hline \multicolumn{3}{|l|}{ Workplace } \\
\hline Hokkaido \& Tohoku & 13 & 14 \\
\hline Kanto \& Koshinetsu & 15 & 17 \\
\hline Chubu & 20 & 22 \\
\hline Kinki & 6 & 7 \\
\hline
\end{tabular}




\begin{tabular}{lrr}
\hline \hline Chugoku \& Shikoku & 19 & 21 \\
Kyushu \& Okinawa & 18 & 20 \\
Job position & 1 & 1 \\
President & 3 & 3 \\
Executive officer & 50 & 55 \\
Manager & 9 & 10 \\
Assistant manager & 26 & 29 \\
Staff & 2 & 2 \\
Other & & \\
Duration of service in convention industry & 6 & 7 \\
Less than one year & 37 & 17 \\
One to three years & 15 & 8 \\
Four to six years & 7 & 29 \\
Seven to nine years & 26 & \\
More than ten years & & 40 \\
Number of international convention you have & & 21 \\
attracted before & 36 & 18 \\
None & 19 & 8 \\
One to two times & 16 & 8 \\
Three to five times & 6 & \\
Six to ten times & 7 & 7 \\
Eleven to twenty times & & \\
More than twenty-one times & & \\
\hline \hline
\end{tabular}

\subsection{Measurements of the respondents' evaluation}

Table 2 presents the descriptive analysis of 20 items, which consisted of 5 domains; accommodation \& dining, facility, cooperation system, tourism, and access to information.

In terms of "accommodation \& dining", the highest mean score was "presence or absence of vegetarian and halal meals in regional hotels or restaurants' $(M=4.23)$. 'Presence or absence of various four-star or five-star hotel' $(M=4.10)$ and the third highest mean score, 'various catering companies in the region' $(M=4.09)$ were almost the same mean score. 'Presence or absence of various foreign-affiliated hotels' $(M=3.58)$ was the lowest mean score. This item was the highest standard deviation $(S D=1.184)$.

Regarding "facility", 'flexibility of booking and use' $(M=4.68)$ was the highest mean score in all items of the questionnaire survey. The second highest mean score, 'cheap rate for convention facility usage' $(M=4.24)$. 'Presence or absence of an inspection program in which convention bureaus incur the travel costs' received mean score of 3.84.

For "cooperation system", the highest mean score was "presence or absence of a structure for cooperation among convention bureaus, facility, staff and hotel staff to attract international conventions' $(M=4.81)$. The second highest mean score was 'presence or absence of a structure for cooperation among convention bureaus, city or prefectural officials to attract international conventions' $(M=4.63)$. The third highest mean score was 'sufficient subsidy or grant to hold a convention' $(M=4.54)$. 'Presence or absence of a structure for cooperation between convention bureaus and professional congress organizers (PCO) to attract international conventions', 'meeting with key persons such as a mayor, vice mayor, prefectural governance or vice governor', 'presence or absence of staff members with the Certified Meeting Professional (CMP) qualification' received mean scores of 4.13, 4.09, and 3.24 respectively. 
Concerning "tourism", mean scores of 'proud unique culture to foreigners', and 'variability of resources for tourism which can be utilized in excursions after international conventions' were 4.46 and 4.40 .

In terms of "access to information", the highest mean score was "variability of public transportation' $(M=4.53)$. The second and third highest mean scores were 'a lot of information about hotels in English' $(M=4.42)$, and 'a lot of information about the region in English' $(M=4.41)$. The other questionnaire items, 'a lot of information about facilities in English' and 'discretion of PR about the city environment' received mean scores of 4.38 and 3.57 respectively.

Table 2: Measurement of the respondents' evaluation

$(\mathrm{N}=91)$

\begin{tabular}{|c|c|c|}
\hline Question items & Mean & SD \\
\hline \multicolumn{3}{|l|}{ Domain 1: Accommodation \& Dining } \\
\hline 1. Presence or absence of various four-star or five-star hotels & 4.10 & 1.012 \\
\hline Presence or absence of various foreign-affiliated hotels & 3.58 & 1.184 \\
\hline Various catering companies in the region & 4.09 & .890 \\
\hline $\begin{array}{l}\text { 4. Presence or absence of vegetarian and halal meals in regional } \\
\text { hotels or restaurants }\end{array}$ & 4.23 & .731 \\
\hline \multicolumn{3}{|l|}{ Domain 2: Facility } \\
\hline 5. Cheap rate for convention facility usage & 4.24 & .835 \\
\hline Flexibility of booking and use & 4.68 & .648 \\
\hline $\begin{array}{l}\text { 7. Presence or absence of an inspection program in which } \\
\text { convention bureaus incur the travel costs }\end{array}$ & 3.84 & .834 \\
\hline \multicolumn{3}{|l|}{ Domain 3: Cooperation System } \\
\hline $\begin{array}{l}\text { 8. Meeting with key persons such as a mayor, vice mayor, pre- } \\
\text { fectural governance or vice governor }\end{array}$ & 4.09 & .852 \\
\hline 9. Sufficient subsidy or grant to hold a convention & 4.54 & .655 \\
\hline $\begin{array}{l}\text { Presence or absence of a structure for cooperation among } \\
\text { convention bureaus, city or prefectural officials to attract } \\
\text { international conventions }\end{array}$ & 4.63 & .626 \\
\hline $\begin{array}{l}\text { Presence or absence of a structure for cooperation among } \\
\text { convention bureaus, facility, staff and hotel staff to attract } \\
\text { international conventions }\end{array}$ & 4.81 & .445 \\
\hline $\begin{array}{l}\text { Presence or absence of a structure for cooperation between } \\
\text { convention bureaus and professional congress organizers } \\
\text { (PCO) to attract international conventions }\end{array}$ & 4.13 & .846 \\
\hline $\begin{array}{l}\text { 13. Presence or absence of staff members with the Certified } \\
\text { Meeting Professional (CMP) qualification }\end{array}$ & 3.24 & .874 \\
\hline \multicolumn{3}{|l|}{ Domain 4: Tourism } \\
\hline 14. Proud unique culture to foreigners & 4.46 & .620 \\
\hline $\begin{array}{l}\text { 15. Variability of resources for tourism which can be utilized in } \\
\text { excursions after international conventions }\end{array}$ & 4.40 & .665 \\
\hline \multicolumn{3}{|l|}{ Domain 5: Access to Information } \\
\hline 16. A lot of information about the region in English & 4.41 & .683 \\
\hline 17. A lot of information about facilities in English & 4.38 & .711 \\
\hline A lot of information about hotels in English & 4.42 & .716 \\
\hline
\end{tabular}


19. Discretion of PR about the city environment

Note: Professional Congress Organizer (PCO) is a job which specializes in the creation, production, and implementation of conventions and events.

Certified Meeting Professional (CMP) established in 1985 is a program which regarded as international standard of excellence in the meetings, conventions, and exhibitions industry.

In table 3, 20 items are divided into two groups: non-experienced and experienced convention bureaus and are shown in the descriptive analysis.

In terms of "accommodation \& dining", 'presence or absence of various foreign-affiliated hotels' showed the biggest differences between non-experienced and experienced convention bureaus in all items. Concerning "facility", all items showed almost the same mean score in non-experienced and experienced convention bureaus. For "cooperation system", mean score of experienced was higher than that of non-experienced convention bureaus in most items. Regarding "tourism", all items showed similar results in non-experienced and experienced convention bureaus. The results of "access to Information" showed similar mean score in some items, but mean score of experienced was slightly higher than that of non-experienced convention bureaus in 'discretion of PR about the city environment'

Table 3: Measurement of non-experienced and experienced

$(\mathrm{N}=91)$

\begin{tabular}{lll}
\hline \hline Question items & Mean & SD \\
\hline \hline
\end{tabular}

Domain 1: Accommodation \& Dining

1. Presence or absence of various four-star or five-star hotels

Non-experienced

Experienced

2. Presence or absence of various foreign-affiliated hotels

Non-experienced

$2.97 \quad 1.190$

Experienced

$3.98 \quad 0.981$

3. Various catering companies in the region

Non-experienced

$3.89 \quad 0.965$

Experienced

4. Presence or absence of vegetarian and halal meals in regional hotels or restaurants

Non-experienced

Experienced

$4.36 \quad 0.584$

\section{Domain 2: Facility}

5. Cheap rate for convention facility usage

Non-experienced

Experienced

6. Flexibility of booking and use

Non-experienced

$\begin{array}{ll}4.64 & 0.787\end{array}$


Experienced

$4.71 \quad 0.528$

7. Presence or absence of an inspection program in which convention bureaus incur the travel costs

Non-experienced

$3.83 \quad 0.833$

Experienced

$3.84 \quad 0.826$

\section{Domain 3: Cooperation System}

8. Meeting with key persons such as a mayor, vice mayor, pre-

fectural governance or vice governor

Non-experienced

$4.00 \quad 0.850$

Experienced

$4.15 \quad 0.840$

9. Sufficient subsidy or grant to hold a convention

Non-experienced

$4.47 \quad 0.799$

Experienced

$4.58 \quad 0.529$

10. Presence or absence of a structure for cooperation among convention bureaus, city or prefectural officials to attract international conventions

Non-experienced

$4.58 \quad 0.640$

Experienced

$4.65 \quad 0.610$

11. Presence or absence of a structure for cooperation among convention bureaus, facility, staff and hotel staff to attract international conventions

Non-experienced

$4.78 \quad 0.478$

Experienced

$4.84 \quad 0.416$

12. Presence or absence of a structure for cooperation between convention bureaus and professional congress organizers

(PCO) to attract international conventions

Non-experienced

$4.36 \quad 0.630$

Experienced

$3.98 \quad 0.924$

13. Presence or absence of staff members with the Certified

Meeting Professional (CMP) qualification

Non-experienced

$3.11 \quad 1.021$

Experienced

$3.33 \quad 0.740$

\section{Domain 4: Tourism}

14. Proud unique culture to foreigners

Non-experienced

$4.39 \quad 0.722$

Experienced

$4.40 \quad 0.535$

15. Variability of resources for tourism which can be utilized in excursions after international conventions

Non-experienced

$4.42 \quad 0.718$

Experienced

$4.49 \quad 0.621$

\section{Domain 5: Access to Information}

16. A lot of information about the region in English

Non-experienced

$\begin{array}{ll}4.22 & 0.786\end{array}$

Experienced

$\begin{array}{ll}4.53 & 0.567\end{array}$ 
17. A lot of information about facilities in English

Non-experienced

$4.31 \quad 0.700$

Experienced

$4.44 \quad 0.707$

18. A lot of information about hotels in English

$\begin{array}{lll}\text { Non-experienced } & 4.31 & 0.700\end{array}$

Experienced

$4.49 \quad 0.710$

19. Discretion of PR about the city environment

Non-experienced

$3.31 \quad 0.775$

Experienced

$3.75 \quad 0.768$

20. Variability of public transportation

Non-experienced

$4.53 \quad 0.726$

Experienced

$4.53 \quad 0.567$

\subsection{Multivariate regression}

Table 4 presents the results of the logistic regression that the p-values are below .05 in all questionnaire items.

In ' $\mathrm{Q} 12$ presence or absence of a structure for cooperation between convention bureaus and professional congress organizers (PCO) to attract international conventions', the non-experienced convention bureaus had more positive opinions than the experienced convention bureaus. On the other hand, the experienced convention bureaus had more positive opinion than the non-experienced convention bureaus in ' $\mathrm{Q} 2$ presence or absence of various foreign-affiliated hotels.

There were no significant differences of the respondents' opinions on the other items between the non-experienced and experienced, indicating similarities in their opinions.

Table 4: Differences between non-experienced and experienced convention bureaus

\begin{tabular}{lcccccc}
\hline & B & S.E & Wald & df & Sig. & Exp(B) \\
\hline $\begin{array}{l}\text { Presence or absence of vari- } \\
\text { ous foreign-affiliated hotels }\end{array}$ & .709 & .335 & 4.484 & 1 & .034 & 2.033 \\
\hline $\begin{array}{l}\text { Presence or absence of a } \\
\text { structure for cooperation be- } \\
\text { tween convention bureaus and } \\
\text { professional congress organ- }\end{array}$ & -1.639 & .577 & 8.066 & 1 & .005 & .194 \\
$\begin{array}{l}\text { izers (PCO) to attract interna- } \\
\text { tional conventions }\end{array}$ & & & & & & \\
\hline $\mathrm{R}^{2}=.347$ (Cox-Snell), .470 (Nagelkerke) & & & & & & \\
\hline \hline
\end{tabular}

Dependent variable: non-experienced $=0$, experienced $=1$

Independent variables: 20 items (Table 2)

\section{Discussion}

The findings indicated that 'presence or absence of a structure for cooperation among convention bureaus, facility staff and hotel staff to attract international conventions' showed an exclusively high mean score. Also, in order to attract international convention, the results point out that it is important to have relationships among convention bureaus, facility staff, 
city or prefectural officials, and PCO. Moreover, wide-range cooperative structure will be required for attracting international convention.

In addition, 'flexibility of booking and use', 'sufficient subsidy or grant to hold a convention', and 'variability of public transportation' are more than 4.50 mean score. 'flexibility of booking and use' was second highest score in all items. If the bookings of facility or accommodation is flexibility, it will give a host an advantage.

The questionnaire items which are below 4.00 in descriptive analysis were 'presence or absence of various foreign-affiliated hotels', 'presence or absence of staff members with the Certified Meeting Professional (CMP) qualification', and 'discretion of PR about the city environment'. Regarding the difference between non-experienced and experienced convention bureaus, experienced emphasis on importance of various foreign-affiliated hotels. Very few people have CMP qualification in Japan, so it seems that the importance of CMP qualification as a profession standard is not universally recognized.

In multivariate regression, the experienced convention bureaus have more positive opinions than the non-experienced, regarding 'presence or absence of various four-star or five-star hotels'. The reason why the experienced convention bureaus have a positive opinion is that to build foreign-affiliated hotels in host city makes the host city better known and as a consequence, name recognition of host cities helps to attract international convention.

On the other hand, non-experienced convention bureaus consider 'presence or absence of a structure for cooperation between convention bureaus and professional congress organizers (PCO) to attract international conventions' as an important factor. This result does not say that the non-experienced convention bureaus are inferior to the experienced convention bureaus in their professional consciousness. However, non-experienced convention bureaus think that to sharing information and collaborate with congress organizers helps to attract international convention.

The present study has some limitations. In order to secure the valid responses, researchers had to eliminate the invalid responses despite the fact that 101 questionnaires were collected. Moreover, it is necessary to discuss how the mutual collaboration among stakeholders can contribute to attract international convention.

\section{Acknowledgement}

The authors are grateful to Dr. Norihisa Komoda from Code Solution K.K for useful discussion. This was partially supported by JSPS KAKENHI Grant Number 17K13311.

\section{References}

[1] T. Roger, "Conferences and Conventions 3rd edition: A Global Industry," Routledge, to be printed in 2013.

[2] Japan Tourism Agency. Economic Impact of Tourism on Japan. Retrieved September 25, 2017, from http://www.mlit.go.jp/common/001182932.pdf

[3] C. K. H. Lau, S. Milne, and C. S. Johnston, "MICE, ICT and local economic development: The case of Te Kahurangi, New Zealand," Journal of Convention \& Event Tourism, vol.7, no.1, pp. 61-75, 2005. 
[4] S. S. Kim, K. Chon, and Y. K. Chung, "Convention industry in South Korea: an economic impact analysis," Tourism Management, vol. 24, no. 5, pp. 533-541, 2003

[5] Japan Tourism Agency. Tourism Nation Promotion Basic Plan. Retrieved June 16, 2017, from http://www.mlit.go.jp/common/000208713.pdf

[6] M. Ha, and C. Love, " Exploring content and design factors associated with convention and visitors bureau web site development: an analysis of recognition by meeting managers," Journal of Convention \& Event Tourism, vol. 7, no. 1, pp. 43-59, 2005.

[7] Y. X. Lehto, Y. D. Kim, and M. A. Morrison, "The effect of prior destination experience on online information search behaviour," Tourism and Hospitality Research, vol. 6, no. 2, pp. 160-178, 2006.

[8] M. Oppermann, "Convention destination images: analysis of association meeting planners' perceptions," Tourism Management, vol. 17, no. 3, pp. 175-182, 1996.

[9] G. I. Crouch, and J. R. Brent Ritchie, "Convention site selection research: A review, conceptual model, and propositional framework," Journal of Convention \& Exhibition Management, vol. 1, no. 1, pp. 49-69, 1998.

[10] H. Qu, L. Li, and G. Chu, "The comparative analysis of Hong Kong as an international conference destination in Southeast Asia," Tourism Management, vol. 21, no. 6, pp. 643-648, 2000.

[11] C. Chen, "Applying the analytical hierarchy process (AHP) approach to convention site selection," Journal of Travel Research, vol. 45, no. 2, pp. 167-174, 2006.

[12] J. E. Whitfield, "Why and how UK visitor attractions diversify their product to offer conference and event facilities," Journal of Convention \& Event Tourism, vol. 10, no. 1, pp. 72-87, 2009.

[13] S. S. Kim, Y. Guo, and J. Agrusa, "Preference and Positioning Analyses of Overseas Destinations by Mainland Chinese Outbound Pleasure Tourists," Journal of Travel Research, vol. 44, no. 2, pp. 212-220, 2005.

[14] K. Weber, and W. S. Roehl, "Service quality issues for convention and visitor bureaus," Journal of Convention \& Exhibition Management, vol. 3, no.1, pp.1-19, 2001.

[15] H. Iwamoto, T. Matsuo, T. Fukushima, and N. Komoda, "The self-image of Japanese local cities as a convention host by tourist bureaus," proceedings of ITC's 15 International Tourism Congress, pp. 1-8, 2015.

[16] H. Iwamoto, T. Matsuo, T. Fukushima, and N. Komoda, "Convention bureaus' evaluation of their regional characteristics," proceedings of 5th IIAI International congress on Advanced Informatics, pp. 813-818, 2016.

[17]H. Iwamoto, T. Matsuo, T. Fukushima, and N. Komoda, "On the convention bureau's evaluation of its regional characteristics and convention facilities," Information Engineering Express International Institute of Applied Informatics, vol. 2, no. 3, pp. 21-31, 2016. 